\title{
Assessment and feedback practices in the EFL classroom
}

\author{
Ida Ayu Made Sri Widiastuti*
}

Universitas Mahasaraswati Denpasar

Jl. Kamboja No. 11A, Dangin Puri Kangin, Denpasar Utara, Kota Denpasar, Bali 80233, Indonesia

${ }^{*}$ Corresponding Author. E-mail: idaayuwidia@unmas.ac.id

\begin{tabular}{ll} 
ARTICLE INFO & ABSTRACT \\
\hline $\begin{array}{l}\text { Article History } \\
\text { Submitted: }\end{array}$ & $\begin{array}{l}\text { The present study explored the implementation of Language classroom assessment } \\
\text { 13 January 2021 }\end{array}$ \\
$\begin{array}{l}\text { Revised: } \\
\text { and feedback within the English as a Foreign Language (EFL) classroom. This } \\
\text { research was conducted using a qualitative research design, and the obtained data were } \\
\text { Accepted: }\end{array}$ & $\begin{array}{l}\text { analyzed descriptively. Data were collected by conducting direct classroom observation } \\
\text { using observation checklists and in-depth interviews with the three professional }\end{array}$ \\
$\begin{array}{l}\text { English instructors using an observation guide. The data were transcribed and coded } \\
\text { according to their categories. The findings of the study indicated that the students }\end{array}$ \\
$\begin{array}{l}\text { Keywords } \\
\text { assessment; feedback; } \\
\text { practices; EFL classroom }\end{array}$ & $\begin{array}{l}\text { Verbal feedback was merely provided by the teachers, and feedback was given only } \\
\text { occasionally. The teacher hardly provided any follow-up action in order to modify } \\
\text { their way of teaching. Consequently, there was a slow, gradual improvement of the }\end{array}$ \\
Scan Me: & $\begin{array}{l}\text { students' learning achievement. Therefore, teachers were recommended to utilize } \\
\text { various classroom language assessments to assess the students' learning. The teachers } \\
\text { should provide both verbal and written feedback for their students to enhance their }\end{array}$ \\
achievement continually.
\end{tabular}

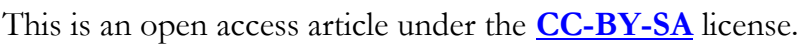

How to cite:

Widiastuti, I. (2021). Assessment and feedback practices in the EFL classroom. REID (Research and Evaluation in Education), 7(1), 13-22. doi:https://doi.org/10.21831/reid.v7i1.37741

\section{INTRODUCTION}

The most recent recommendations from the 2013 Curriculum suggested that assessment should be conducted to measure the students' knowledge, attitudes, and skills. To assess the three domains, the 2013 curriculum recommends five assessment characteristics: mastery learning, authentic, employing predetermined assessment criteria, and using various assessment techniques. Assessing the domain attitudes, direct or indirect observation, self-assessment, peer assessment, and journal are utilized by the teachers. Competency achievement is assessed by monitoring the learning process, learning progress, and competency achievement in conjunction with the students' potency and ability, which are expected to improve.

The assessment of knowledge is carried out by measuring the students' mastery, including factual, conceptual, and procedural knowledge at various levels of thought processes (Widiastuti, 2018, pp.2-5). Assessment can also provide feedback to teachers in order to correctly plan and carry out the learning process. Moreover, the assessment helps teachers obtain useful feedback on what, how much, and how well they are learning (Taras, 2005, pp.468-471).

Assessment is conducted through a series of steps, including planning, assessment preparation, and information collection through an amount of evidence showing the students' achievement, processing, and utilization of information about the student's competence. Assessment in the 2013 curriculum is intended primarily to "diagnose" students' learning progress toward accomplishing the standards. Diagnostics assessment is administered to map out the students' ability in areas of language dimension. Additionally, a diagnostics assessment is also conducted to 
identify the students' weaknesses to enable teachers to practice better learning treatment. Assessment is carried out to measure the holistic achievement of learning competencies (Widiastuti et al., 2020).

Diagnostics assessment is administered to map out students' ability in areas of language dimension. Additionally, a diagnostics assessment is also conducted to identify the students' weaknesses to enable teachers to practice better learning treatment. Summative assessment is often called assessment of learning because its specific purpose is merely to know students' strengths and weaknesses (Stiggins, 2002; McMillan et al., 2013).

In general, assessment can be classified into two distinctive types of assessment: summative and formative assessment. Both of these assessments are administered to collect the students' learning achievement. Some specific purposes create differences in both assessment practices. To measure the students' learning achievement, teachers usually conduct the summative and formative assessment at the end of the school term in one semester. Additionally, the summative assessment functions help teachers organize the upcoming lesson and nailing down how the next lesson should be designed and practiced in the classroom.

Meanwhile, formative assessment is intended to measure the students' learning progress and teachers have a clear picture of the students' achievement in a particular learning unit. This is an ongoing assessment conducted at the completion of every learning unit, and then the result of the formative assessment can be used as a learning device to improve teaching and learning practices, so that is why formative assessment is frequently termed assessment for learning (Stiggins, 2002; McMillan et al., 2013, p.2; Derrick \& Ecclestone, 2006, p.3). Moreover, Black and Wiliam (1998, p.25) emphasize that assessment is carried out with the aim of obtaining data about student abilities. Feedback is given to make the students attain higher achievement in learning. The primary assessment is carried out by the teacher through observation during a certain period of time and attitude assessment is not carried out on every basic competency (Widiastuti \& Saukah, 2017, p.52).

Formative assessment is used to assist students in learning by giving them the opportunity to assess their work based on their learning progress - feedback for various types of teacher-made tests and performance assignments such as student portfolios. Therefore, assessment is critical in learning because it allows teachers to provide practical instruction in evaluating students' competence (Tante, 2018, p.43). On the other hand, feedback is also a significant thing in the perspective of education. One of the most powerful influences on learning is feedback. Feedback is the essential aspect of effective teaching and learning. It is a significant viewpoint in assessment and as a basis for advancing the students' achievement. It can make the students move forward and utilize themselves to make improvements in learning. Appropriate formative feedback may improve students' achievement and improve teachers' pedagogical practices (Black \& Wiliam, 1998, p.22; Dunn \& Mulvenon, 2009, p.2).

'To speed up the students' improvement in learning feedback is a vital thing that should be provided by the teachers. Feedback is a part of formative assessment implementation because every formative implementation should be followed by formative feedback. It is used to enhance the students' progress in learning which helps the teachers and students to know their existing position. Feedback also enables the students to attain better ability and quality of their work. It also gives students chances to modify the upcoming classes (Box et al., 2015, p.22). Consequently, after implementing formative assessment, the teachers should provide formative feedback to give a clear overview of their learning.

Several studies have been conducted which mainly focused on investigating the process of the assessment implementation administered by the teachers in the classroom (e.g. Taras, 2005; Stiggins, 2002; Ahsan, 2009). There was, however, very limited information on how the corrective feedback was given by the teachers. Thus, this study was highly important to be conducted to reveal the assessment and feedback practices carried out by the EFL teachers in the real classroom settings. 
Considering the aforementioned phenomenon, this paper aims to provide the information of the assessment and feedback practices of junior high school teachers focusing on the English teacher's assessment practices, the teachers' understanding of assessment, and their feedback after implementing formative assessment.

\section{METHOD}

A qualitative research approach was employed in examining and interpreting the data of this study. Participants in this study were obtained by conducting an interview with several junior high school English teachers. Data were collected from three junior high school English teachers as indicated by their teaching qualifications and having at least two years of teaching experience. The study participants are also necessary to accomplish the criteria of being a qualified teacher, which can be seen from their teaching certificate and has the same understanding of classroom assessment. Data were collected using in-depth interviews and classroom observation. Constant comparative techniques of each participant's interviews were used to recognize the teachers' assessment and feedback practices. The collected data were firstly transcribed and interpreted critically and argumentatively. To ensure the validity of the data, the triangulation process was conducted by matching the data collected from the interviews and the data collected from the observation. Prior to triangulating the data, the transcriptions of the interviews were also checked several times to ensure their compliance with the recordings, and then teachers were asked to read the transcriptions to reconfirm what they said during the interviews. The transcriptions then were carefully matched with the observation notes to ensure all the data were valid and reliable.

\section{FINDINGS AND DISCUSSION}

\section{Assessment Used by the Teachers in EFL Classes}

The result of the interview with the English teachers showed that English teachers in this study did not know the English curriculum. They think that the curriculum is similar to the lesson plan or syllabus they used. The teachers in this study have a significantly clear understanding of the importance of administrating assessments. It was found that they were able to carry out some assessments. The term formative assessment is often called a daily assessment. They also administered summative assessments at the end of the school term. When they were asked the purpose of conducting a formative assessment, they answered a sufficiently comprehensive description. The assessment was mainly administered because it was required by the school rather than for learning and teaching improvement. Therefore, formative assessment was conducted to test the students' ability and show their score for a particular topic. The formative assessment was conducted, but the result was not adequately modulated to improve teaching and learning processes.

Most of them stated that the assessments were conducted based on the assessment guidelines stated in the curriculum. Teachers in this study clearly understand the purpose of conducting classroom assessments. Two main types of assessment conducted by teachers in assessing the students' learning ability: formative and summative evaluation.

\section{Summative and Formative Assessment Practiced in English Classes}

To measure the students' knowledge at the end of each semester Summative assessment is conducted; however, the formative assessment was conducted at the last part of every learning unit, which is known as "daily repetition."

\footnotetext{
"I think any assessment is important to be administered in the classroom. I do a summative assessment in the classroom at the end of each semester intending to know my students' learning achievement and formative assessment at the end of each learning unit." (Teacher B)
} 
"I administered a formative assessment to find out whether or not the students understand the lesson. I usually give the students assessment at the end of every learning unit, which I usually give after finishing teaching by giving them a short test. This I do in order I know the one unit of the assessment which I have done usually conducted at the end of every unit of learning students' understanding about the lesson and give the students score for that learning unit. I also administer a summative test at the end of every semester to give the students score for one semester." (Teacher A)

The English teacher administers a summative assessment to get information about the students' ability. The main objective of administering summative assessment is to assess the students' ability by scoring the student learning outcomes for one school term. In contrast, the formative assessment was conducted at the end of every learning unit to know the students' progress in the classroom. It is a very clear distinction between the purpose of summative and formative assessment. Both are important to carry out for the sake of higher education quality.

The excerpt of the interview above demonstrated that teachers in this research comprehend the contrast between developmental formative and summative assessment implementation. During the interview, the teachers also explained that they are willing to learn more about the formative and the summative assessment. This indicates that the teachers did not yet fully understand those two assessments. It was noted that teachers had various comprehension of how formative assessment implementation. The teachers understood that formative assessment is really useful to enhance the students' performance, but they did not really practice the result of formative assessment to modify the teachers' teaching strategy to make learning improvement especially on their teaching style. The teacher merely uses the result of the formative assessment to assess the students' performance. Additionally, the teachers did not usually communicate the formative assessment result accompanied by feedback to the students.

Based on the teacher's interviews, the teacher did not know exactly the purpose of conducting the formative assessment. They conducted the assessment based on the school's prevailing policies so that the continuation of the assessment results was not done maximally. In this study, it was found that formative assessment was conducted by using several types of tests.

"I often administered formative assessment; however, I did not use the results of the assessment to modify my teaching strategy. I do this to meet the policy in the 2013 curriculum." (Teacher A)

"Formative assessment for me is very important to do. When the formative assessment time comes, I ask my students to continue doing the coursebook exercises. This is easier for me because I don't need to write a new test, and the students are already familiar with the test or exercise format. I score the students' work as soon as possible and then return them to the students. By returning their works after being marked, the students know their ability straight away." (Teacher B)

The aforementioned interview excerpt indicated that the teacher conducted a formative assessment in their teaching practice because the teacher believed that formative assessment is helpful to identify the students' learning progress. However, the teacher did not adequately prepare the assessment to ensure that the assessment is conducted in line with the learning objective and learning competence. The teacher in this study asked the students to do extra exercises from the coursebook. In practice, this could be acceptable if the coursebook is designed to suit the learning standard, and the tests are designed to meet the learning objectives and learning competence. Based on the classroom observation, the coursebook was mainly designed to develop the students' language competence, and it was not for assessing the students. It can then be said that the teacher is required to construct the test accordingly.

Additionally, the teacher explained that the formative assessment was not used to modify the teaching style. The formative assessment's primary purpose is to enhance the learning process. Formative assessment result gives a significant input for the teacher in order to figure out a new teaching strategy if the students' ability in that particular test was not sufficiently accepted. The students' weaknesses do not merely cause the poor student's achievement, but also because of the teacher's inappropriate learning strategy. That is why the formative assessment should be 
respected in its nature to improve teaching and learning quality. It can be said that formative assessment is a golden solution to teaching and learning challenges because it allows teachers and students to work together to make the quality of learning progressively excellent.

Concerning the summative assessment administration, teachers in this study have almost similar views regarding its purpose and how and when it should be administered. The summative test is administered at the end of every semester or end of the school academic term. This assessment is mainly intended to give a clear picture of the students' achievement for a certain period after a particular semester's learning syllabus is completed.

"Summative assessment is administered at the end of the semester. I usually work with the school principal, in this case, the vice-principal of education affairs. He set an assessment schedule, and I just prepared the test and administered it to the students. To make easier, I usually downloaded the test from the internet and compiled them to make a set of 50 multiple choice test." (Teacher C)

This excerpt of the interview indicated that a summative assessment was administered by the teacher at the end of the semester or school academic term to measure the students' ability for a period of time. The teacher's test construction procedure seemed unacceptable since most test items were taken from the internet. The teacher's consideration to download the test items from the internet is not in line with good test construction characteristics. In any test construction, the teacher needs to develop a test based on the learning objectives and learning competence that guided the teacher during the learning process. Getting the test items from the internet is more likely to cause a new problem in testing since the test items available on the internet are not valid and reliable for assessing the students in every school. Therefore, test items should be really constructed by respecting the syllabus content for that semester or school academic term.

"For me, summative assessment is not really important. I usually combined and compiled the students' daily works and daily assessments to figure out their abilities. I can score their ability by critically judging the results of their works and daily assessment. Daily assessment will show me their progressive achievement, so it is necessary to do a summative assessment, which requires money and special time. It is a good way to assess students, but for me, it is not visible and impractical." (Teacher A)

The interview expert's expert showed that this teacher was not really keen on conducting summative assessment because it is not practical and time-consuming. Scoring the students through a collection of daily works and daily assessments is considered more practical and economical. This teacher seemed to be in favor of measuring the students based on daily assessments and daily assignments. This teacher might give accurate scores for the students if the class size is ideally small. The teacher has adequate time allocation to analyze all the students' work and daily assessment critically. However, recently it was compulsory for the school to administer the summative assessment in order to assess the students' learning achievement appropriately.

On the other hand, problems of using formative assessment to improve the teaching and learning quality were found by the teachers for the time they had. The follow-up action was not carried out by the teachers after implementing the formative assessment. This was obtained from interviews conducted with teacher $\mathrm{C}$.

\section{"I cannot use formative assessment results well because, after the daily test, I have to continue the learning activities by discussing the next material to finish all the material before the end of the semester." (Teacher C)}

In accordance with interviews and observations administered to the three English teachers, it was found that there are several types of tests used in assessing the students' learning ability in the classroom. This study indicated that several different types of questions were used by teachers for assessing the students' comprehension of learning. A type of activity used to assess the students' comprehension was the question-and-answer session. However, the question-and-answer session focused only on the teacher asking questions to the students, and the students were not given an opportunity to ask any question to the teacher. The teacher asked questions according to the material that has been previously taught. The students raised their hands and answered the 
teacher's questions according to their abilities. Most of the students' questions were answered in front, and only some students who were sitting in the middle and at the back answered the teachers' questions.

As previously mentioned, the finding is in line with the finding of Ahsan (2009, p.234) and Rahman (2018, p.278), in their study that students were actively answered the teachers' questions. However, the questions were mainly requiring the students' lower level of a cognitive domain, which merely measured the students' knowledge of recalling the learning material. The questions were in the form of open-ended questions, closed-ended questions, yes/no questions; questions were directed to individual students and questions to the whole group. The teachers questioned the close-ended questions allowed students to answer using one or two words. Most students answered easier questions, but many found difficulty answering more complicated and comprehensive questions.

Similarly, the data obtained from the observation also confirmed that the three English teachers used several questions in assessing the ability of students, such as; closed-ended questions, open-ended questions, and yes-no questions. The teachers administered close-ended questions to get a brief and specific answer from the students. In this study, the teachers gave several closed-ended questions to the students related to the material being discussed.

"I usually give close-ended questions if I ask my students years, such as birth year, production year, etc., it is also bappening when I ask about a place or when I need a specific answer." (Teacher C)

"Close-ended question is usually given if I need a short answer to my question. Students usually answer the question briefly. But this type of question did not give an appropriate explanation."(Teacher B)

"I usually give an open-ended question to my students, so they can explain the answers they provide, from the students' answer. I know how far my students understand the material being studied. It takes more time, so not all students can get the question."

Besides giving a specific answer, the purpose of providing close-ended questions is to minimize the test's time allotment, and each student has the opportunity to answer all questions presented by the teacher. Time allotment for learning is very limited due to many topics. Learning competence needs to be taught to the students. The teachers consider close-ended questions to take a shorter period of answering. Ideally, adequate time should be allocated to ensure that all students are assessed properly with sufficient tests. Without doing assessment appropriately may confuse the judgment process of the ability. Additionally, it makes it harder to grade the students' achievement.

Furthermore, an open-ended question is the teacher's type of question, which aims to provide opportunities to the students to explore their answers. In this case, the student can provide more than one answer and an explanation of the teacher's questions. In this study, teachers usually provide an open-ended question to obtain a lot of information about the students' learning achievement. In this case, the question was given to know the students' understanding in the classroom; however, this type of question has weaknesses because not all students can answer them well. The students could not respond to the teachers appropriately. They can usually mention the desired answer but cannot explain it in detail.

Open-ended questions were provided by one of the teachers to determine the students' ability. He asked students to mention and explain the type of paragraph writing. Some students can mention it well, but they cannot explain it appropriately. The teacher gave the same question to other students, without giving them any feedback. On the other hand, the questions have also varied, which is given individual and questions for the whole class. Individual questions are usually given to determine the ability of each student. Teachers provide some questions to students. Teachers usually invited each student to answer the questions they asked. If the student could not answer, then the questions were given to another student. Some teachers, in this case, did not provide any explanation about the answer whether the answer asked by the students appropriate or not. 
Based on the classroom observations, it was also found that the questions to the whole class were given by the teacher after providing explanations about the particular material or showing a picture to the students. Teachers provided questions in accordance with the picture. Students who were able to answer were raising their hands and answer the teacher's questions. In this case, not all students can answer teacher questions. One teacher in this study said that he gave a question to convey the students' understanding by providing a detailed explanation of the teacher's questions.

Based on the data obtained, it can be seen that the types of questions mostly offered by the teachers in order to assess the achievement of students were close-ended questions, whether the questions were given individually or to the whole classes. The teacher conducted this to provide specific answers and minimize the time provided. Another fact that was obtained in this study was when the teacher gave open-ended questions to the students, most students replied with a close-ended style. In this case, the student tried to answer the teacher's question with one or two words only. According to the teacher, it was usually done by the students in the classroom, and the teacher could not give a further explanation because of the limited time of the assessment.

Based on the classroom observation conducted, the teachers rarely gave feedback after their students responded to their questions. Based on the result of this study, it can be seen that the most technique used by teachers to assess the students' ability was the question. This study found that teachers gave more close-ended questions to the students and rarely gave open-ended questions. On the other hand, the students still answered with a close-ended question, even though the teacher gave open-ended questions. The students' answers might be caused by their limited ability to elaborate on the answers. Therefore, students need to be more intensively practice their English to express their opinion elaborately.

Further studies were also conducted by researchers and revealed similar findings (Burns \& Myhill, 2004, p.38; Ahsan, 2009, p.234; Yang, 2010, p.184). The findings indicated the teachers' questions were answered by students in one or two words when they were asked closed or yes/ no questions. Yang (2010, p.184) also proved that students were trying to respond more comprehensively when they were asked by using open-ended questions. However, the students were able to answer in more words only when teachers pushed them to describe more elaborately. This study proved that students were willing to speak more English words when they feel that they need to be explained further. The teacher often uses open-ended questions to encourage students to speak English more intensively, using more than one or two words. Moreover, Black and Wiliam (2009, p.11) suggested that the teachers need to plan the questions before asking them to avoid asking the same questions.

The aforementioned data indicate that two types of assessments were conducted by teachers to measure the students' achievement of learning. Formative assessment was usually administered at the end of every learning unit, and summative assessment was administered at the end of the school term. The teachers in this study seem to understand the principle of assessment execution; however, most of the teachers had poor ability to properly conduct the assessment and made use of the assessment result. In the practice of formative assessment, for example, teachers did not use the result to improve their teaching processes. Most of the teachers focused on establishing the students' achievement scores after taking the assessment.

\section{Feedback Practices in EFL Classes}

Based on the classroom observation and interviews conducted with the three teachers in this study, it was found that feedbacks were given by teachers to the students after administering different types of assessment in the classes; however, providing any feedback to students was not a regular practice. Feedback is an important component of the teaching and learning process. The data revealed that the teachers gave two forms of feedback namely written and oral feedback.

In accordance with teacher $A$, the feedback was an interaction between teachers to students and students to other students. Feedback helps students understand the mistakes they have made, 
so students reached the target faster. Feedback was given not only for the whole class but also for individual students. In this study, teachers mainly provided verbal feedback to the students and written feedback on a writing task.

"I usually give feedback to the students, both spoken and written feedback. This is important to develop the students' learning achievement and make them ready for the upcoming lesson. My feedback is sometimes in the form of a very strong suggestion to ensure my students do them properly."

Types of the feedback given by the teacher in this study were sometimes positive and negative feedback. Teachers provided positive feedback to improve the performance of students. The teachers paid attention seriously, take notes, and directly respond to the students' answers. Sometimes teachers provided negative feedback. In general, it was revealed that teachers asked any questions to the students and sometimes gave feedback on those responses. For example, teacher $\mathrm{C}$ taught reading skills in the classroom. Teacher $\mathrm{C}$ invited the students to read aloud; when the student made mistakes in reading, the teacher correctly made a mistake. Another fact that was found in this study was the other student also assisted the reader when they made a mistake in reading, so the students themselves also gave feedback to each other.

In this study, teachers described that feedback should be provided to the students regularly because it could inspire students. They mention that they gave feedback to the students; however, many teachers may not understand the role of feedback for students in the learning period. Teachers rarely give feedback to students because they only focused on finishing the topic being discussed. This is also influenced by their culture, where a teacher gave explanations to students without allowing students to do something. It causes the teacher to focus on delivering the material. On the other hand, it made teachers rarely provide feedback on students. Teachers gave feedback when students do test/repetition questions where students have no chance to ask questions. Usually, teachers provide feedback numbers without any comments about students. Students need written feedback, not only numbers but also comments from teachers.

"Sometimes I give feedback to our students; however, the feedback is not regularly provided after conducting assessment because sometimes I think it is important to give feedback since questions bave been answered by the students." (Teacher C)

"Of course, feedback is very important. I provide feedback in my classes. Feedback will belp the students to correct their mistakes. Students get inspiration from the feedback given by the teacher." (Teacher A)

Feedback can have a good effect on students because feedback students feel that the teacher paid attention to them. Besides, feedback makes students more active in doing something. It can improve students' learning ability because students are understood about the mistakes they make and get encouragement from the teacher to continue to enhance their ability and justify the error. Feedback has an important role, both for students and teachers. Feedback is an important factor that support students to be successful in the learning process (Decristan et al., 2015, p.1136). Feedback can be in the form of corrections and suggestions for Students. This may contain criticism or encouragement for better performance. Feedback is important for the teacher to correct the mistakes that have been made.

\section{CONCLUSION}

Assessment is vividly essential to conduct and administer according to the prime purposes of assessment practices. Summative assessment is administered accordingly to determine the students' ability for a certain period of time. In contrast, formative assessment was administered at the end of every learning unit to measure the students' progressive achievement toward a particular learning competence. The teachers mostly used open-ended and closed-ended questions to assess the students' achievement of learning. Feedback was required to be provided to the students to gain higher learning achievement and arouse their active learning. Positive corrective feedback certainly leads to successful learning, meanwhile, the result of formative assessment could also be 
used for teachers as their reflection of the teaching style and to modify their fossilized teaching strategy into a more effective way of teaching. It, therefore, implies the need for a closer and stronger relationship between universities and schools to organize more intensive and practical development programs for the teachers to enrich their competence in carrying out the assessment and feedback practices in the classroom.

\section{REFERENCES}

Ahsan, S. (2009). Classroom assessment culture in secondary schools of Dhaka City. Teacher's World, 33-34(9), 231-244.

Black, P., \& Wiliam, D. (1998). Assessment and classroom learning. Assessment in Education: Principles, Policy \& Practice, 5(1), 7-74. https:/ / doi.org/10.1080/0969595980050102

Black, P., \& Wiliam, D. (2009). Developing the theory of formative assessment. Educational Assessment, Evaluation and Accountability, 21(1), 5-31. https://doi.org/10.1007/s11092-0089068-5

Box, C., Skoog, G., \& Dabbs, J. M. (2015). A case study of teacher personal practice assessment theories and complexities of implementing formative assessment. American Educational Research Journal, 52(5), 956-983. https://doi.org/10.3102/0002831215587754

Burns, C., \& Myhill, D. (2004). Interactive or inactive? A consideration of the nature of interaction in whole class teaching. Cambridge Journal of Education, 34(1), 35-49. https://doi.org/10.1080/0305764042000183115

Decristan, J., Klieme, E., Kunter, M., Hochweber, J., Büttner, G., Fauth, B., Hondrich, A. L., Rieser, S., Hertel, S., \& Hardy, I. (2015). Embedded formative assessment and classroom process quality: How do they interact in promoting science understanding?. American Educational Research Journal, 52(6), 1133-1159. https://doi.org/10.3102/0002831215596412

Derrick, J., \& Ecclestone, K. (2006). Formative assessment in adult literacy, language and numeracy programmes: A literature review for the OECD. Centre for Learning, Teaching and Assessment Through the Lifecourse, University of Nottingham.

Dunn, K. E., \& Mulvenon, S. W. (2009). A critical review of research on formative assessment: The limited scientific evidence of the impact of formative assessment in education. Practical Assessment, Research and Evaluation, 14(7), 1-11. https://doi.org/10.7275/jg4h-rb87

McMillan, J. H., Venable, J. C., \& Varier, D. (2013). Studies of the effect of formative assessment on student achievement: So much more is needed. Practical Assessment, Research \& Evaluation, 18(2), 1-15. https://doi.org/10.7275/tmwm-7792

Rahman, M. M. (2018). Exploring teachers practices of classroom assessment in secondary science classes in Bangladesh. Journal of Education and Learning, 7(4), 274-283. https://doi.org/10.5539/jel.v7n4p274

Stiggins, R. J. (2002). Assessment crisis: The absence of assessment for learning. Phi Delta Kappan, 83(10), 758-765. https://doi.org/10.1177/003172170208301010

Tante, A. C. (2018). Primary school teachers' classroom-based assessment feedback culture in English language. International Journal of Educational Research Review, 3(4), 32-47. https://doi.org/10.24331/ijere.425151

Taras, M. (2005). Assessment - summative and formative - some theoretical reflections. British Journal of Educational Studies, 53(4), 466-478. https://doi.org/10.1111/j.14678527.2005.00307.x 
Widiastuti, I. A. M. S. (2018). Teachers' classroom assessment and grading practices. SHS Web of Conferences, 42(00052), 1-7. https://doi.org/10.1051/shsconf/20184200052

Widiastuti, I. A. M. S., Mukminatien, N., Prayogo, J. A., \& Irawati, E. (2020). Dissonances between teachers' beliefs and practices of formative assessment in EFL classes. International Journal of Instruction, 13(1), 71-84. https://doi.org/10.29333/iji.2020.1315a

Widiastuti, I. A. M. S., \& Saukah, A. (2017). Formative assessment in EFL classroom practices. Babasa dan Seni: Jurnal Bahasa, Sastra, Seni dan Pengajarannya, 45(1), 50-63. https://doi.org/10.17977/um015v45i12017p050

Yang, C. C. R. (2010). Teacher questions in second language classrooms: An investigation of three case studies. Asian EFL Journal, 12(1), 181-201. Retrieved from https://www.asianefl-journal.com/main-editions-new/teacher-questions-in-second-language-classrooms-aninvestigation-of-three-case-studies/ 